This item was submitted to Loughborough's Research Repository by the author.

Items in Figshare are protected by copyright, with all rights reserved, unless otherwise indicated.

\title{
Global sport mega-events and the politics of mobility: The case of the London 2012 Olympics
}

PLEASE CITE THE PUBLISHED VERSION

http://dx.doi.org/10.1111/1468-4446.12103

\section{PUBLISHER}

(c) London School of Economics and Political Science. Published by Wiley

\section{VERSION}

AM (Accepted Manuscript)

\section{PUBLISHER STATEMENT}

This is the peer reviewed version of the following article: GIULIANOTTI, R. ...et al., 2015. Global sport megaevents and the politics of mobility: The case of the London 2012 Olympics. British Journal of Sociology, 66(1), pp. 118-140, which has been published in final form at https://doi.org/10.1111/1468-4446.12103. This article may be used for non-commercial purposes in accordance with Wiley Terms and Conditions for Use of SelfArchived Versions.

\section{LICENCE}

CC BY-NC-ND 4.0

\section{REPOSITORY RECORD}

Giulianotti, Richard, Gary Armstrong, Gavin Hales, and Dick Hobbs. 2014. "Global Sport Mega-events and the Politics of Mobility: The Case of the London 2012 Olympics". Loughborough University. https://hdl.handle.net/2134/21891. 


\title{
Global Sport Mega-Events and the Politics of Mobility:
}

The Case of the London 2012 Olympics

\begin{abstract}
Richard Giulianotti (Loughborough University \& Telemark University College, Norway)
\end{abstract}

Gary Armstrong (Brunel University)

Gavin Hales (University of Essex)

Dick Hobbs (University of Essex)

\begin{abstract}
This paper examines the politics of mobility which surrounded the London 2012 Olympics. We provide a critical discussion of the mobility conflicts, problems and criticisms which emerged from our research with local people in the Stratford and wider Newham areas of London, where most Olympic events were located. The paper is divided into four broad parts. First, we identify and discuss the relevant components of the 'mobilities paradigm' in social science which underpin our analysis. Second, we briefly outline our research methods, centring particularly on fieldwork and interviews with different social groups. Third, we examine in detail the six main themes of mobility politics which were evident at London 2012, relating to social context, event construction, event mobility systems, commercial mobilities, the mobile politics of exclusion, and contested modes of mobility. In doing so, we seek to extend the mobilities paradigm by introducing various concepts and keywords -
\end{abstract}


notably on the three-speed city, entryability, mobility panics, instrumental mobility, and corporate kettling - which may be utilized by social scientists to examine mobility systems in other social contexts. We conclude by reaffirming the significance of mobility-focused research at sport and other mega-events, and by indicating future lines of inquiry for social scientists.

\section{Keywords}

Mobilities; Olympics; Sport Mega-Events; Globals; Exclusion; Mobility Panic

Total Word Count: 9,816 (incl. abstract)

Forthcoming publication in British Journal of Sociology

\section{(ORIGINAL MANUSCRIPT)}

This is the Author's Original Manuscript in its final and definitive form. The Version of Record can be found via the following reference:

Giulianotti, R., G. Armstrong, G. Hales and R. Hobbs (2015) 'Global Sport Mega-Events and the Politics of Mobility: The Case of the London 2012 Olympics', British Journal of Sociology, 66(1): 118-140. Available at: http://onlinelibrary.wiley.com/doi/10.1111/1468-4446.12103/full 


\section{Introduction}

The London 2012 Olympic and Paralympic Games were widely hailed in the UK and overseas as a huge success: all event venues were built as planned, most sport events were outstanding, Team GB accumulated a record medal haul, the UK public provided huge support, and no significant security incidents were reported. Yet, beyond the spectacular sport and starry headlines, the build-up and implementation of the London Games germinated a diverse range and substantial volume of social conflicts, problems and criticisms.

Many of these concerns centred on mobility issues, such as Olympic visitors facing long delays at Heathrow, or how London's transport system would cope with additional Olympic traffic. This focus on mobility has a particular significance for social scientists, as some have argued that a mobilities 'turn' or 'structure of feeling' has taken hold, engendering a new 'mobilities paradigm' of social research (Cresswell 2006; Kaufman 2010: 367; Thrift 1996: 259; Urry 2007: 6)

In this paper, we draw heavily on the mobilities paradigm to examine in detail the critical mobility issues and struggles surrounding the London 2012 Olympics. Our particular focus is on the events prior to and during the Olympic Games in the Stratford and wider Newham area of East London, where the Olympic events and facilities were primarily based and where we undertook extensive qualitative research.

Social scientists have investigated prior Olympic Games and other sports megaevents with reference to a wide range of themes and issues, such as the rituals and ideologies of Olympism, spectator practices and subcultures, media discourses, the 
cultural politics surrounding minority groups, and policing and security. ${ }^{1}$ The influence of the mobilities paradigm has been more circumscribed, with two separate papers, on the Barcelona 1992 and London 2012 Olympics, exploring mainly how event-hosting intersects with the making and remaking of global cities (Degen 2004; Urry 2008). In a short paper, Urry (2008: 293-4) argues that the staging of the Olympics and other global events is embedded within:

a neo-Mediaeval world which we now seem to inhabit - a world of empires (Microsoft, Olympics, Google); of city-states (such as London, Beijing, Barcelona, Athens, Dubai, Singapore); and of wandering minstrels or sports stars plying their trade wherever their city-states can attract them for a passing moment before they return to their tax-free gated fortresses.

As we seek to demonstrate, the mobilities paradigm remains a highly insightful yet relatively untapped sociological approach for examining in detail the Olympics and other hallmark or mega-events in sport or other fields (for example, cultural exhibitions, trade fairs, political summits, world economic and social forums). More broadly, this research field is of growing significance for social scientists as, since the late 1980s, mega-events in sports, culture, politics and business have expanded substantially in their number, diversity of themes, economic scales, social impacts, and degrees of international prestige for host cities and nations.

Accordingly, the aim of the paper is three-fold. First, we seek to fill a significant research gap by forwarding the first extensive and systematic analysis of the hosting of a global mega-event with reference to mobility systems and practices, issues and

\footnotetext{
1 See, for example, Bourdieu (1998), Chatziefstathiou and Henry (2012), Cornelissen (2012), Giulianotti (2011), Klausen (1999), Lenskyj (2008), MacAloon (1981), Roche (2000), and Rowe (2012).
} 
conflicts. Second, we seek to advance the mobilities paradigm in social science, by introducing supporting concepts and keywords (such as the 'three-speed city', 'entryability', 'mobility panic', 'instrumental mobility', and 'corporate kettling'), and by identifying six main mobility issues and conflicts which arose at the Olympics. These concepts, keywords, mobility issues and conflicts are research-portable; that is, they may be utilized by social scientists to investigate mobility processes and politics at other mega-events. Third, more broadly, we seek to advance sociological understanding of the Olympics and other global events, and of how arising mobility issues impact on host cities. Thus, our main findings may be extended to examine other sport mega-events, cultural festivals and urban gatherings where specific mobility systems are planned, implemented, experienced and contested.

While engaging fully here with the mobilities paradigm, we should emphasize that we recognize the value of other theoretical and methodological approaches for investigating and analysing sport, mega-events and urban life. Indeed, our prior and continuing work in these fields draws on, for example, structuralist and poststructuralist perspectives, theories of globalization and 'glocalization', urban history and historiography, and classic qualitative methods such as ethnography and group interviews. ${ }^{2}$ However, in the context of this paper, we cannot extend our use of these theories and methods in the purely for reasons of brevity; nor are we able to explore other important substantive aspects and issues surrounding London 2012, such as the event's political economy and economic geography, the staging of the Paralympic Games, and anti-Olympic movements and protests.

\footnotetext{
2 See for example Armstrong (1996), Giulianotti (1999), Giulianotti and Robertson (2004), Hobbs (1989).
} 
Our discussion is separated into four main parts. We begin by setting out the key components of the mobilities paradigm which underpin our analysis. Second, we briefly explain the mobile research methods which we deployed to gather data. Third, and most substantially, we examine six specific fields of mobility politics that were played out in the build-up to, and during, the 2012 Olympics. Fourth, we conclude by discussing the sociological value of the mobilities paradigm, the significance of mega-events for mobilities research, and issues for future study.

\section{The Mobilities Paradigm}

Since the late 1990s, the mobilities paradigm of research and analysis has undergone rapid development, with John Urry and colleagues as chief architects, and important further contributions stemming from a wider circle of social scientists. ${ }^{3}$ Briefly stated, the paradigm focuses on "the diverse mobilities of peoples, objects, images, information, and wastes; and of the complex interdependencies between, and social consequences of, such diverse mobilities" (Sheller and Urry 2006: 2011). In disciplinary terms, the mobilities paradigm is principally underpinned by sociology and human geography; thus, this paradigm helps to shift social scientific focus from the theme of socio-economic mobility (such as relative mobility in the class structure) to socio-spatial mobility (Urry 2007: 6). The mobilities paradigm also has substantial continuities with several major themes and theories within sociology since the late 1980s - notably postmodernity, reflexive modernization, globalization, risk society,

\footnotetext{
${ }^{3}$ See for example Urry (2000a, 2000b, 2002, 2003, 2007, 2008); Büscher and Urry (2009); Büscher, Urry and Witchger (2010); Cresswell (2006); Elliott and Urry (2010); Kaufman (2010); Knowles (2010); Sheller and Urry (2006); Thrift (1996).
} 
complexity, and liquid or second modernity ${ }^{4}$ - as evidenced by the prior work within, or favourable discussions of, these research fields by leading mobilities theorists.

The mobilities paradigm highlights the social significance of key contemporary mobility systems, processes and issues, which include new social media and telephony; prosthetic and disability technologies; transnational viral pandemics such as SARS or avian flu; transnational circuits of production and consumption; migration and tourism; expanding transport hubs and connectivities; and, climate change and global warming (Urry 2000a, 2000b, 2002, 2007). Thus, it is possible to identify "five interdependent 'mobilities' that produce social life" across distances:

- the corporeal or embodied travel of people;

- the physical movement of objects;

- communicative travel, such as in person-to-person messages

- imaginative travel, such as through visual and print media

- virtual travel, such as through digital technologies for transferring money or information

(Elliott and Urry 2010: 15-16)

To maintain pace with these mobile social transformations, some leading advocates of the mobilities paradigm argue that sociology and other social sciences should depart from old-style 'sedentarist' methods and pursue instead more mobile research techniques, to keep up with the moving social phenomena under investigation (cf. Büscher and Urry 2009; Büscher, Urry and Witchger 2010; Sheller and Urry 2006: 208-9).

\footnotetext{
${ }^{4}$ See Bauman (2000), Beck (2000), Beck, Giddens and Lash (1994), Byrne (1998), Harvey (1990), Lash and Urry (1994), Robertson (1992).
} 
The themes of power and the politics of mobility tend to be embedded rather than explicitly addressed within the mobilities literature. In the discussion that follows, we understand power and politics as being integral to - rather than analytically or experientially separable from - mobility systems, processes and practices. Thus, for example, the planning, construction and implementation of any mobility system (such as an Olympic transport system) is an inherently political process that is shaped and negotiated through different power relations; and, these power relations may themselves be constituted in mobile and broader, non-mobile (particularly politicaleconomic) ways.

Following from this, four specific points arise with respect to how the mobilities paradigm engages with issues of power and politics. First, echoing Virilio's (1986) 'dromological' social theory, wherein power relations are defined and manifested through speed of movement, some proponents of the mobilities paradigm draw attention to different scales of mobile inequality. Thus, relative inequality marks the divisions between the fast and slow lanes of mobility, while absolute inequality is established when one person's mobility is dependent upon the immobilization of others (cf. Beckmann 2001). Those with greater resources have higher levels of motility: the capacity to choose to move when, where, how, and at what speed (Beckmann 2001: 23-4). Typically, motility is actualized by accessing fast lanes and rapid modes of movement, while overtaking or immobilizing those with lower resources.

Second, and extending Bourdieu (1984), power relations are foregrounded by forms of network or mobility capital which 'point to the real and potential social relations that mobilities afford' (Elliott and Urry 2010: 59). 'Core elements' of network or mobility capital include appropriate documentation, welcoming hosts, invitations to 
visit distant places and associates, the physical ability to move freely and to make use of mobility objects, secure meeting points, access to key transport systems, and the financial and temporal resources to manage all of these (Elliott and Urry 2010: 10-11). The highest volumes of mobility capital are possessed by 'globals': elites with lives of 'relentless travel' who have gained most from the rapid expansion of global capitalism since the 1960s (Bauman 1998: 99; Elliott \& Urry 2010: 80). 'Globals' have greater resources of 'exitability' or escape motility, and are thus able to avoid being involuntarily immobilized (cf. Bauman 1998; Elliott \& Urry 2010: 78-9). We would add here that globals also possess resources of 'entryability': that is, the capacity to access prized modes of mobility or to enter into restricted travel routes and modes of transport. Moreover, we would argue that the mobility capital of these globals is significantly predicated on their high levels (varyingly mixed) of other capital (economic, cultural, social, and symbolic).

Third, modes of mobility are not equal; some prevail over others. Automobility in particular dominates other everyday mobilities such as walking, cycling, or rail, as demonstrated by the prioritization of car and road in UK transport policies, urban design and planning, work and consumption spaces, and the mobility systems of diverse institutions. Historically, automobility has played a critical role in the shift away from 'neighbourhood lives', with their 'slow mobilities' of walking and cycling, towards lives 'beyond neighbourhood', wherein work, education and leisure are conducted increasingly beyond fixed territories (Elliott and Urry 2010: 116-9).

Fourth, significant forms of self-empowerment and additional motility are available to those with mobile and transnational social lives. 'Portable personhoods' are created through increasingly long-distance and mobile relationships with life partners, family, friends, work colleagues and employers (Elliott \& Urry 2010: 102-3). 'Miniaturized 
mobilities' - small mobile technologies such as mobile phones, Blackberries, laptops, and iDevices - are integral to portable personhoods, affording 'mobile connectivity' and a 'liberation from place' through the 'continuous coordination of communications' (Elliott \& Urry 2010: 28-32). While devices such as mobile phones have become ubiquitous features of mass consumer society, the distribution of the most sophisticated and advanced communication technologies of course continues to be significantly dependent on political-economic factors.

Diverse mobility systems - such as roads, railway links, cycle-lanes, mobile phone networks, wifi zones and communication network providers - serve to organize, sort and shape the mobile lives of diverse populations (Urry 2007: 51-2). These systems are increasingly interdependent or interconnected, and enabled by forms of expert knowledge. They also 'afford' mobility, drawing people into usage, while differentiating users particularly by speed: thus, in corporeal travel, the divisions between motorists, rail passengers, cyclists and pedestrians; and in communicative or virtual travel, the divisions between roaming wi-fi access, high-speed broadband, low-speed dial-up, or no online access.

Finally, two significant points should be made regarding the social reach and hold of advanced mobility systems. First, while some aspects of the mobilities paradigm concentrate on the fluidity and 'flows' of everyday social life, the social experience of mobility and mobility systems is typically rather more uneven and precarious: people bump and stumble into each other, urban transport systems come to a halt, computer systems 'crash', and networks 'go down' (cf. Knowles 2010). The risk of system disruption or collapse is omnipresent, through inherent faults, unanticipated effects, or forms of hostile intervention (which may themselves utilize other mobility 
systems) (Urry 2007: 53). Hence, substantial time, money and expertise are directed towards security and risk management within complex mobility systems.

Second, face-to-face meetings and other forms of 'thick co-presence' remain central to urban sociality (cf. Boden and Molotch 1994). This 'compulsion of proximity' serves to concretize friendships, families, work teams and other social networks, particularly in 'ambient places' such as the kitchen table, the pub, the local café, the church, the neighbourhood park (Boden and Molotch 1994; Elliott and Urry 2010: 534). High levels of mobility - driving alone to work, switching jobs, living in zones of transition - may vitiate these social bonds, although alternative forms of mobility may substitute, such as long-distance travel to meetings, cheap international calls, video communication technology, or online virtual communities (cf. Puttnam 2000: 204; Vertovec 2004; Wellman 2001). Moreover, it is increasingly likely that some participants will be required to travel long distances in order to attend face-to-face meetings and to maintain significant social networks.

These components of the mobilities paradigm illuminate contemporary mobile social lives, and provide the key theoretical tools for the analysis of our research data from London 2012. Before turning to explore mobility politics at London 2012, we set out below our research methods for this paper.

\section{Methods}

The research for this paper was primarily undertaken in the London Borough of Newham, which is located in the city's old East End, on the north bank of the Thames. Our particular research focus was on the Stratford area, positioned in the 
north-west corner of Newham, and where the Olympic Park was situated. ${ }^{5}$

Supplementary research was conducted in Olympic locations elsewhere in Newham and London. ${ }^{6}$

Data was collected by drawing heavily on the mobile methods advocated by the mobilities paradigm (Büscher and Urry 2009; Büscher, Urry and Witchger 2010; Cresswell 2006; Sheller and Urry 2006; Urry 2007: 39-42). Mobile ethnographic research and participant observation was conducted 'on the move' with diverse research groups: walking, driving, cycling and travelling by rail and underground throughout Stratford and other parts of Newham; on or inside roads, pavements, cycle-paths, walkways, shopping malls, and trains; and, at 'transfer points' of movement, such as waiting rooms, departure points, and transport termini, where the transitions between immobility and mobility occur. Further, cyber-research was undertaken to explore the virtual and imaginative mobilities of individuals, social groups, and institutions (Sheller and Urry 2006: 217-9).

In addition to these recommended mobile methods, we investigated historical and demographic forms of mobility, and undertook more spatially fixed forms of qualitative research. We consulted documentary sources (such as local authority reports, census statistics) and academic literature (particularly historical), and also conducted interviews in specific locations with local stakeholders, to acquire data on population movements, prior forms of mobility, and how mobility was experienced by relevant social groups.

\footnotetext{
5 The Olympic Park hosted the Olympic Stadium, Aquatics Centre, Basketball Arena, Copperbox Riverbank Arena, Velopark, Water Polo Arena, and Athletes' Village.

6 These locations included the ExCel Arena in the Royal Docks area of Newham, and Greenwich Park, Horse Guards Parade, Hyde Park, and Wembley Stadium, elsewhere in London.
} 
Fieldwork was carried out by a team of four researchers over a three-year period, before, during and after London 2012. We were particularly concerned to experience and observe the mobility systems in place for London 2012 , and to explore their everyday negotiation and interpretation by different stakeholders. In total, 53 semi-structured interviews relevant to this paper were undertaken with key local stakeholders including those in transit, local residents, business people and employees, politicians, council officers, police officers, community groups, and antiOlympic movements. As we set out below, mobility issues were recurring concerns and subjects of discussion for these diverse stakeholders. ${ }^{7}$

\section{Mobility Issues in the Olympic City}

Our research identified six major mobility issues that centred on London 2012. These issues relate to social context, event construction, event mobility systems, commercial mobilities, the mobile politics of exclusion, and contested modes of mobility. These mobility issues, which may be referenced to investigate other hallmark or major urban events, are examined in turn below.

\section{i) Social Context: Stratford/Newham within the Global Olympic City}

Turning first to consider the event setting, Stratford and the wider Newham area have long been subject to relatively negative and problematic mobility pressures, which typify the inhabitants' low levels of motility or mobile capital, and more broadly their lack of power over mobility systems and processes. Newham's population has been defined by marginal forms of mobility, notably through the arrival of waves of poor migrants from the UK, Ireland, mainland Europe, the Caribbean, south and east

\footnotetext{
${ }^{7}$ We followed the guidelines of the British Sociological Association (2002) in implementing ethical research practice. We sought and secured the informed consent of all research participants; each person's identity was anonymised in recording and storing data, and writing up research findings.
} 
Asia, and Africa. The borough's old mobility economy, built along the docklands, collapsed in the 1980s, and Newham was then largely by-passed as post-industrial gentrification and urban rebranding swept through London's East End. Recent official data positions Newham as the $6^{\text {th }}$ most deprived local authority in England, with only $56.7 \%$ of the population aged $16-74$ in employment, and with by far the highest levels of household overcrowding (25.4\%). ${ }^{8}$ Newham is also the UK's most ethnically diverse borough, with over 110 different languages spoken, and $71 \%$ listed as 'non-White'. ${ }^{9}$ Add to that a large, submerged, vulnerable population of refugees and illegal migrants with little or no mobility capital or forms of 'personal personhood' (such as work visas), and a 'vernacular cosmopolitanism', steeped 'in marginality' can be seen to typify the borough (Bhabha 1996:195-6). At the same time, several local people noted to us that the youthful and multicultural aspects of Newham's demography had been carefully exploited at key moments by London's Olympic bid. For example, in 2005, at the Olympic meeting in Singapore where the 2012 Olympics hosts were decided, 38 local children had been flown out in advance to support the London bid, alongside 'globals' such as Blair, Beckham and Coe, to symbolize the transnational diversity of the proposed host borough.

Newham also features large, relatively powerless populations that continue to be pressed into movement. While conclusive statistical data is difficult to access, many of our research groups informed us that the Stratford area, where short-term rented property predominates, features particularly high 'churn' levels (annual household

\footnotetext{
8 See http://www.communities.gov.uk/documents/communities/pdf/733520.pdf; http://data.london.gov.uk/datastorefiles/documents/2011-census-snapshot-labour-market.pdf. ${ }^{9}$ See http://data.Iondon.gov.uk/datastorefiles/documents/2011-census-snapshot-ethnic-diversityindices.pdf; http://www.ons.gov.uk/ons/rel/census/2011-census/key-statistics-for-local-authorities-inengland-and-wales/rft-table-ks201ew.xls. One school which we visited within a mile of Olympic Park reported 52 first languages that were used by less than 400 registered pupils.
} 
moves). The arrival of the Olympics is understood to have simply intensified this dislocation as landlords sought to capitalize by raising rents to push out existing tenants.

Consequently, there are significant weaknesses in 'communicative mobilities' across local populations: neighbourhood compulsions to proximity and social bonds are low, while information flows between different authorities and citizens are reportedly poor and haphazard, reflecting relatively limited levels of everyday political influence over the negative effects and pressures of mobility (cf. Wellman 2001). As one senior police officer informed us:

If you want a sign of the churn, look at all the 'to let' signs on properties, and the amount of mattresses and other household rubbish that's left behind in gardens or on the street from people moving. Newham residents don't complain because they are so used to it, but if you were in most other London boroughs you'd have a load of complaints.

(Dave, senior Newham police officer and former resident) Alternatively, in areas of high churn, local people draw on 'imaginative' and 'virtual' mobilities to maintain relatively strong links with fellow national or cultural migrants, and with friends and family 'back home'. These ties are facilitated particularly through miniaturized mobilities (particularly mobile phones), and the numerous businesses in Newham which trade in international phone cards, internet access, mobile phones, and money transfers, as well as visa advice to safeguard or enhance 'portable personhoods'. 
Thus, to summarize, long-term and relatively negative mobility pressures, weak levels of local communicative mobility, and high levels of churn served to characterize the marginal social context in which the London Olympics were located.

\section{ii) Event Construction: The Olympic Movement in Stratford/Newham}

When Olympic preparations began in Newham, mobility politics were manifested through the enforced movement of significant sections of the Stratford populace, to facilitate the construction of London 2012 venues and facilities. To initiate the development of the 560-acre Olympic Park, compulsory purchase orders were served by the London Development Agency on over 400 residents on the Clays Lane housing cooperative and over 200 local businesses, while a cooperative of local allotments was also displaced. Post-Olympics, over 11,000 new homes were planned for the Park, most for the private market, with around one-third set to be classified as 'affordable housing', yet reports indicated they would remain well beyond the financial reach of most local people (The Independent, 2 July 2012). For some displaced residents, the Park's development represented a fundamental shift in political control over local land, as one stated to us:

This is a land grab. It's about removing from some people what they have and giving it to some other people, and in the process not adequately compensating those people who have been deprived of what they had.

(Jonathan, former Clays Lane resident)

As at the 1992 Barcelona Games, the Olympic development constituted one of several major capital infrastructure and regeneration projects across Newham, including the Thames Gateway (stretching through south-east England) and the 
Stratford City plan (encompassing Westfield, claimed to be 'Europe's biggest urban shopping mall', adjacent to Olympic Park) (cf. Degen 2004). Adjoining the Park was the Carpenter's Estate housing complex, built in 1969, whose fate depended on Games-related regeneration. Earmarked by Newham council for sale to developers, over half of the estate's 700 households had been gradually decanted, but proposed deals dragged on for years, immobilizing the remaining tenants who were unable to plan their futures. During interviews, local people regularly complained about the lack of council information and guidance from council officials. Some local people formed a protest movement (Carpenters Against Regeneration Plans), while an exhibition of photographs, mounted on boarded-up flat windows, captured the stress and trauma endured by elderly residents in having to abandon their homes.

Residents on Carpenter's and other estates near Olympic Park criticized their exposure to the negative, mobile environmental impacts of Olympic construction and development. As one commented to us:

Actually, it's been a nightmare. We've had so much dust you can't put your washing out, there's been the noise from the building work, and the PA getting tested, helicopters flying, and testing the lights, so the place is lit up like daylight at 4 o'clock in the morning. It's been terrible, really.

(Alan, resident, Carpenter's Estate)

Overall, Olympic-related urban redevelopment, including the construction of event facilities, registered the low levels of mobility capital of many local populations. Event-related development generated substantial negative mobile impacts and externalities on different social groups, including the forced movement of households and businesses and the immobilizing of others. 
iii) Event Mobility Systems: The Three-Speed City and Mobility Panics

The Olympic mobility system was one of the most contentious issues surrounding the event, attracting widespread criticism within the political, media and public domains. The system encompassed all transport routes in the London area and beyond that supported the Olympics, including the Olympic Route Network (ORN) which comprised 280 miles of special traffic measures and restrictions on key roads. The mobility system provided a study in Olympic-related power relations: its broad impact was to establish, in our analysis, a three-speed city, which differentiated mobile populations according to levels or volumes of mobility capital, while reinforcing both relative and absolute forms of mobility inequality.

First, top speed and fast lanes were reserved for elites - particularly the Olympic 'Games Family', such as sponsors, officials, athletes, and various VIPs - who exercised the greatest political-economic influence over the event. These 'Games globals' possessed high levels of mobile autonomy and exitability, as well as entryability, notably in being granted exclusive entry to special 'Games Lanes': 30 miles of reserved lanes on London's congested roads. Local people, media and opposition groups commonly derided these exclusive routes as 'Zil Lanes', thereby encapsulating a wider set of grievances and criticisms regarding the Games' political elitism and negative mobility impacts, such as increased traffic congestion and the exclusion of the wider public from their habitual transport routes (The Telegraph, 6 June 2012; Independent, 25 July 2012; Guardian, 23 July 2012). On the Games Lanes' debut day, with far fewer road lanes open to the general public, a 32 mile traffic jam was reported on the M4 into London (The Telegraph, 16 July 2012). 
Second, millions of Olympic spectators and visitors were the focus for an Olympic public transport system - mainly rail, underground and bus networks - that delivered steady speed. In exchange for secure passage to Games venues, Olympic spectators and visitors forfeited much of their mobile autonomy or motility, and were typically directed or herded by police, private security, and Olympic volunteers along specified routes. Thus, we regularly observed how teams of private security and volunteers constantly enjoined spectators and visitors to 'keep moving', while forming human or physical barriers to minimize the spillage of people outside these routes and pathways.

Third, slow speed and immobility were most associated with local people and commuters in Newham and elsewhere in London. Many local workers and residents reported to us that they had intentionally 'kept out of the way' or 'stayed at home' whenever possible to avoid the anticipated huge crowds and transport chaos. Olympic parking restrictions were a constant concern for local people, and a dominant subject of discussion and dispute at community meetings with officials from the local authorities. Local people were also aware that their relative immobility shaded into absolute immobility during the Games: the Olympic mobility system required them to get out of the way, to allow Games globals and Olympic spectators and visitors to secure their fast and steady speeds during the event. One local resident informed us of some revelatory comments by London Olympic officials a few weeks prior to the Games:

We had an interesting meeting with them, and they were talking about the Olympic family's transport, and they said, 'What we need to do is we need to take action to reduce the background traffic by $20 \%$ '. And I thought, "Background traffic"? That's me. That's the community, that's the people who 
live here. The thing that's the annoyance to them is that they want to reduce the flow of the people that are going about their daily business.

(Jim, Community Worker, Newham)

One strategy for securing the globals' speed was to dissuade local people and commuters from travelling. Taking the expert role, Olympic organisers, transport officials, and political authorities generated what we term here to be a mobility panic, through warning repeatedly that the city's mobility systems faced massive congestion during the Games. This 'mobility panic' provoked widespread alarm among local people and commuters over travel to and from work, and the provision of key public and social services. In Stratford, public meetings in preparation for the Olympics were dominated by transport issues. Businesses were advised that they would only be able to receive stock overnight (12am-6am) and, with the expectation that local customers and staff would struggle to show up, many considered closure during the Games. Local health providers expressed concerns that patients would be unable to reach them, while churches and funeral directors reportedly advised local people not to die during the Games due to anticipated transport problems in organising and conducting funerals (Newham Recorder, 8 February, 1 March, 2012). Across London, underground passengers were greeted by a loudspeaker message from the London Mayor, Boris Johnson, warning of the need to plan journeys due to "a million extra visitors a day", hence "our roads and public transport services are going to be exceptionally busy, and journeys may take longer than usual".

Two further perceived threats to the fast and steady speeds of Games globals, visitors and spectators emerged before and during the Olympics. First, there were potential failures in technical operations and expert systems. Prior to the Games, 
the fault-prone Docklands Light Railway which served Olympic venues was temporarily suspended; the Jubilee Line which served most Olympic venues suffered recurring signal problems; at Heathrow Airport, three-hour queues of international visitors led politicians to warn that such delays during the Olympics would deter globals and tourists from returning to the UK. Limited expertise and technical guidance among some transport employees and volunteers was reflected on the Games' eve as official Olympic bus drivers transporting the Australian and American teams had no satnav programmes for the Olympic Route Network, were forced into ordinary London traffic, and thus took several hours to reach the Athletes' Village.

Second, there was the potential for industrial action and protests by key employees within the mobility system. Proposed strikes by UK Border Agency staff, tube drivers, and bus drivers were all averted through negotiated settlements in the runup to the Games (The Independent, 30 May 2012; The Guardian, 18 July 2012, 25 July 2012). During the Olympics, cleaners with Transport for London staged several demonstrations outside Stratford train station as part of their campaign to be paid a 'London living wage'. Taxi drivers staged protests in central London against their exclusion from the Games Lanes during the Olympic period, bringing Parliament Square to a halt; several further 'go slows' were also conducted in Stratford (Telegraph, 17 July 2012; Guardian, 24 July 2012).

In the event, the smooth movement of Games globals, visitors and spectators was attributed by many local groups to the unwarranted mobility panic. In Stratford and Newham, local business owners, public service providers and residents commented that expert warnings over overcrowding and congestion had the dysfunctional effect of keeping too many people at home or out of the local area. Several bus and taxi drivers informed us that they had never known London roads to be so quiet, while 
underground passengers reported relatively empty stations and carriages. One market trader told us, "I've no problems getting the stock in here in the morning. All the scaremongering means the roads are really, really quiet. But it's frightened people away" (Dwight, Stratford). Across London, the number of foreign tourists fell by two-thirds, and an estimated 1.5 million workers elected to 'work from home' during the Olympic period (Financial Times, 30 July 2012; Guardian, 30 July 2012).

Overall, the event mobility system's establishment of a three-speed city was underpinned by major power differentials in mobility capital between diverse social groups, and facilitated by mobility panics and by largely efficacious management of potential 'problems' such as industrial disputes. However, the system had notable negative impacts on economic activity, particularly for local businesses, and we explore these issues much more fully in the next section.

\section{iv) Commercial Mobilities: Corporate Kettling and Instrumental Mobilities}

The Games were intended to leverage major urban regeneration and transformation; in the words of Prime Minister David Cameron, to "make sure the Olympics legacy lifts East London from being one of the poorest parts of the country to one that shares fully in the capital's growth and prosperity" (DCMS 2010). However, our research with diverse local stakeholders indicated that, at everyday level, major Olympic-related economic opportunities tended instead to by-pass politically marginalized social groups within Stratford and the wider Newham area. Four main issues relating to commercial mobilities are relevant here.

First, during the long period of Olympic construction work, local residents, employers and politicians complained that Olympic-related jobs and contracts had bypassed 
local workers and businesses, and were instead dominated by migrant workers and outside companies. One local business leader commented to us:

The clarion call from the government and the Olympic games people at the start, that the Olympics are going to be the big lift off for local businesses, has turned out to be a load of rubbish. Some local businesses have been involved, but quite frankly not many, a handful... The same applies to employment.... Most Olympic workers are from outside and coming to live here for a fixed period of time to get the jobs. They aren't local people. The unemployment levels in Newham are ridiculously high and the Olympics have had little or no impact. We are not impressed. We're appalled by it.

(Jim, business representative, Newham)

Second, prior to the Olympics, most local people that we talked to anticipated few direct commercial benefits. Games globals, spectators and visitors were expected to exercise what we term here their instrumental mobility: that is, getting into where they needed to be, getting what they wanted, and getting out as quickly as possible. Instrumental mobility among Olympic globals, spectators and visitors translated into entering Stratford only for the sport, attending the events, and then quickly exiting, to head home or to visit hotels, sights and shops in London's West End. Most locals did not expect many Olympic visitors to book hotels or to tour around in East London.

Third, a stark division emerged between global and local economies, as instanciated most clearly in the differing influences and fortunes of Stratford's two shopping malls. On one side stands Westfield: a $£ 1.4$ billion development, adjacent to Olympic Park and Stratford train station, heralded as Europe's biggest urban mall, one of a global 
chain of such shopping centres owned by the Australian-Israeli Lowy Group, with some 250 retail outlets and 70 restaurants, and filled by transnational brands and corporations associated with national and global consumer cultures. On the other side, literally across the road, stands Stratford Centre: the locale's old shopping mall, serving local people, comprising a mix of market traders and around 50 retail outlets, typically selling low-price and discount goods. Prior to the Olympics, Stratford Centre's functional exterior was hidden by the 'shoal', a £13.5 million art installation of over 100 giant titanium leaves. Many local people expressed concerns to us that, as the 'shiny new' Westfield and Olympic Park developments were opened, the 'old Stratford', 'the other side of the tracks', as best illustrated by the Stratford Centre, would be left behind.

Westfield benefited particularly from the Olympics through the process of what we term here corporate kettling. The word 'kettling' usually refers to the UK police crowd-control tactic of corralling or surrounding large groups of people, particularly public demonstrators, within a designated area that allows no free exit. Here, we forward the term 'corporate kettling' to refer to a more subtle process, whereby physical geography, security measures and expert advice combine to direct and to manoeuvre people into spaces of transnational consumption.

An estimated $70 \%$ of spectators and visitors to Olympic Park arrived at Stratford station and were funnelled directly into Westfield, to stroll along its placeless avenues of transnational consumption, without ever having to cross over to the other side of the tracks, and into 'the old Stratford' (Guardian, 13 September 2011). Thus, Westfield later reported that 5.5 million visits had been made to its mall during the Olympic fortnight, almost $10 \%$ of its annual target (The Telegraph, 15 August 2013). This corporate kettling was achieved in a number of ways: through the explicit 
directions provided by ubiquitous Olympic signs; through shouted directions and guidance from transport employees and volunteers; through the security staff and volunteers at Stratford train station, who sometimes linked arms to create a human shield, effectively barring pedestrians from taking alternative routes away from Westfield and Olympic Park; and, through the advice and guidance given to Olympic visitors on the London underground network, which for example failed to designate some other local stations (such as Stratford High Street) as 'Olympic stations'.

Consequently, beyond Westfield, but only metres from the world's biggest megaevent, Stratford and the rest of Newham were eerily quiet, as local shops and businesses were largely untouched by an 'Olympic effect'. One trader in Stratford Centre informed us:

The footfall here has gone up, but business has definitely gone down - I'm $30 \%$ down on normal, and there are shops here working an extra six hours a day just to keep their sales up to normal. People going into the Olympics are just funnelled out of the railway station and then back again. You see it on the Westfield steps, the huge numbers coming down the first flight of steps go into the station, and then only a few coming down the second set of steps down to the crossing and into this centre.

(Jasmine, market stallholder)

As corporate kettling took hold during the Games, and local streets were visibly empty, Newham authorities endeavoured to attract Olympic visitors into Stratford. Yet attempts to advertise local shops among Olympic visitors were in turn immobilized, as one local councillor explained: 
I'm really very angry with the Olympic organisers. We had our people up in the Westfield area distributing leaflets, trying to do something about it, to encourage people to come over to the [Stratford] Centre. We had prior agreement from Westfield for us to do the leafleting, but the Olympic people came over and said we were not allowed to do this, this was their area, and they confiscated the leaflets. These were Newham Council leaflets!

(Steve, Newham councillor)

Fourth, more broadly, many East London businesses and other initiatives failed to benefit from the Games due to being by-passed or marginalized by the main Olympic mobility systems and networks. We visited a temporary Olympic food market in the Leyton area of East London, in which traders had invested up to $£ 27,000$ in order to access the promised 80,000 daily Olympic visitors. However, the market was located on the far periphery of Olympic routes, attracted hardly any customers, and closed after a few days; in response, traders launched a large petition, claiming they had been 'sold a lie'. ${ }^{10}$ In Greenwich, businesses reported drops in trade, as barriers and signs directed Games visitors away from local shops and into Olympic events. In the Silverton area of Newham, the London Pleasure Gardens, backed by a £3.3 million loan from Newham Council, closed within a week of the Olympics opening, as anticipated Olympic visitors failed to materialize (Newham Recorder, 3 August 2012). Olympic live sites with giant television screens were established in parks across Newham and adjoining boroughs; yet, while very busy for the opening and closing nights, local traders reported disappointing results:

10 See http://www.bbc.co.uk/news/uk-england-london-19292821. 
All of the event parks have been bad for the businesses. The government's done a good job in making this a ghost town. They said it would be jampacked, people wouldn't get moved, so they haven't come out. The local trade has been a lot worse than I expected.

(Sheila, food kiosk, Stratford Park)

Overall, the limited political influence and significance of local people in developing Olympic mobility systems led to relatively circumscribed direct economic benefits from hosting the Games. Games globals, visitors and spectators had few social encounters with Stratford and the wider Newham areas, notably as corporate kettling and instrumental mobilities otherwise directed these Olympic incomers away from sustained local engagement.

\section{v) The Mobile Politics of Exclusion}

The mobile politics of exclusion refer to how forms of mobility were shaped and contested with respect to access to significant social spaces. Three aspects of the socio-spatial politics of exclusion were particularly relevant at London 2012.

First, we have the socio-spatial distribution of prestige events and occasions. Several local stakeholders observed that Stratford, Newham and other parts of East London were merely host sites of convenience for London 2012, being little known and rarely visited by most Londoners, and sources of embarrassment for Games organisers. ${ }^{11}$ As Ingrid, a local resident, commented to us:

Of course you get this in London, you know: "East London is a dump, there's nothing there worth preserving". There's a lot of people from West London

\footnotetext{
${ }^{11}$ See http://www.bbc.co.uk/news/uk-england-london-11387475.
} 
who have never been to East London, which is quite ridiculous. There is this myth that they are in the same city...

Some pointed critically to the Olympic organisers' decision to break with Olympic tradition and the original Olympic bid submission by moving the showpiece Olympic marathon out of the East End and the Olympic Stadium, and into central London which afforded a more 'iconic' backdrop, filled with signifiers of British heritage. In doing so, the Olympic organisers played to the corporeal and imaginative mobilities of those globals and transnational tourists who were attending the Games or watching on television. At the same time, removing the marathon from East London served to immobilize this large part of the capital in symbolic terms, denying it the opportunity to re-present itself in positive ways before national and global audiences.

Second, the distribution of public access (or 'entryability') to prestige events has become a prominent issue in sport in recent years, notably regarding the allocation of tickets or the sale of television rights to pay-TV systems (Giulianotti \& Robertson 2004). At London 2012, most events were heavily over-subscribed; the first-round ballot-based system for distributing tickets received substantial criticism, while the second-round of online sales saw the official website struggle to cope with public demand (Guardian, 24 June 2011, 22 February 2012). Ticket allocation underpinned one prominent media discourse before and during the Olympics which contrasted evidence of corruption and indifference within the Olympic family of globals with the enthusiastic support of ordinary UK spectators. One newspaper investigation uncovered Olympic officials in over 50 countries who were seeking to sell some of their allocated tickets on the black-market for huge profits (The Sunday Times, 17 June 2012). As the Games began, substantial attention was directed at 'sold-out' Olympic events which still displayed vast swathes of empty seats, particularly in 
prime viewing positions. Blame was directed principally at Olympic 'corporate partners' and other Games globals who, having received blocks of free tickets, lacked sufficient motivation to attend (Telegraph, 29 July 2012). In response to extensive criticism, the Olympic organisers mobilized the army, children and Olympic volunteers to plug some of the gaps.

Third, mobility strategies were central to the securing of event spaces at London 2012. Drawing on an official budget of $£ 553$ million, the Olympics mobilized the UK's biggest security operation since 1945, which included tens of thousands of police officers, private security, and armed forces personnel; surface-to-air missiles stationed on tower blocks; and, drone planes and warships as further support.

At everyday level, the core mobility functions of Olympic-related security were to gate-keep entry to venues, maintain fast and steady flows of event visitors, and restrict or control the movement of populations deemed 'out of place' as potential threats to the public relations, images and orders favoured for the event. Thus, the demonstration routes of protest movements were carefully demarcated and monitored; for example, separate protests staged by Tamils and Kashmiris were confined to peripheral locations in Stratford, while a demonstration by one radical Islamist group on the final day of the Olympics was heavily policed and closely observed an agreed route. ${ }^{12}$

Young people from ethnic minorities in and around Stratford reported being particularly affected by security impositions on their movements. Police introduced a

\footnotetext{
12 The different roles of UK and international media, in capturing some of these critical or oppositional 'imaginative mobilities' around the event, were noted by some anti-Olympic protestors. National news media were understood to be disinclined to report on such protests, while international reporters were far more prominent than their UK counterparts in covering anti-Olympic demonstrations or providing critical investigations of the Games's local impacts.
} 
dispersal zone in central Stratford over the Olympic period, establishing an overnight curfew on young people (under 16s), and empowering officers to choose to disperse groups of two or more people from the area. ${ }^{13}$ Internally, the police's specific aim was to exclude gangs from the area, and it was conceded that they would be displaced to other parts of the borough. Given local political sensitivity about any mention of gangs, however, media briefings did not refer to them and instead explained the creation of the dispersal zone as intended to deal with general crime. 'Stop and search' or 'stop and account' powers also continued to be used by police. Thus, for many young people, the Olympic area had become a forbidden space:

You can't go anywhere at the moment. You can't go into Stratford because of the Olympics. Before it was groups of three and more getting moved on, but now it's even ones and twos.

(Steven, young resident in West Ham)

Yet some groups of young people were able to realise their 'compulsion to proximity' by returning or continuing to gather in local spaces. Most notably, in the evenings inside Stratford Centre, young roller-skaters and roller-bladers continued to congregate as normal during the Olympic period, practicing their moves, and rolling and drifting in and around passers-by.

Finally, Olympic preparations also saw the forced movement of other marginal and criminalized groups as part of the broader Olympic cleansing of the Stratford area. For example, the local Council acted to move on homeless people sleeping

${ }^{13}$ These powers are drawn from the Anti-Social Behaviour Act 2003, particularly Section 30. 
rough, apparently displacing them to another part of the borough, and efforts were made to move sex workers out of the area.

Overall, the mobile politics of exclusion surrounding the event were underpinned by three processes - the socio-spatial distribution of prestige events and occasions, the distribution of public access ('entryability'), and the securing of event spaces - which functioned to safeguard the mobility strategies and interests of Games globals vis-àvis Olympic spectators and visitors, and in particular marginalized local people and opposition groups.

\section{vi) Contested Modes of Mobility: Olympic and Public Cycling}

The London Olympics showcased two very different types of engagement with one form of mobility: cycling. On one side, the Olympics provided a transnational platform for national celebrations of elite British cycling at official and popular levels. Before the Games, Bradley Wiggins had become the first Briton to win the Tour de France, while he and other British cyclists such as Sir Chris Hoy and Victoria Pendleton were iconic poster-figures for 'Team GB' and Olympic-related media and advertising. Cycling was also celebrated during the spectacular Opening Ceremony, choreographed by the British film director Danny Boyle, when 75 cyclists on 'dove bikes' pedalled around the Olympic track to symbolize the traditional release of doves, the Olympic message of world peace. During the Games, and to enormous national fanfare, Team GB celebrated a procession of cycling victories, winning 12 Olympic medals, including 8 golds.

National celebrations, symbols and events associated with elite cycling contrasted markedly with the regular everyday social experience of cycling in the UK, as a dangerous, marginalized and contested mode of slow mobility. 122 cyclists were 
killed on UK roads in 2012, ${ }^{14}$ while data from Transport for London showed that 16 cyclists were fatally injured and a further 555 were seriously injured in London in $2011 ;{ }^{15}$ some fatal crash sites are marked by all-white 'ghost-bikes' and other poignant roadside memorials. In the Olympics context, one Olympic Park worker was killed while cycling to work, and a cyclist was struck and killed outside the park during the Games by an official Olympic bus carrying journalists.

At the Olympics, the cultural politics of cycling were most substantially enacted on the evening of the Opening Ceremony. Just outside Olympic Park, to cheers and applause from onlookers, around 200 cyclists emerged and pedalled through central Stratford as part of the Critical Mass bike ride, which is an informal gathering of cyclists staged monthly in London. Police vans and officers later caught up with and 'kettled' most cyclists; 182 people were arrested on the grounds that they might 'cause serious disruption to the life of the community', with particular reference to the Olympics (The Guardian, 29 July 2012). Some participants that we talked to later claimed that police had intervened in part to allow the VIP car of the ultimate global David Beckham - to drive through to the Opening Ceremony; we later heard from some security sources that the Queen's car had nearly been affected by the bike ride. Using mobile phones, some cyclists photographed and filmed the police intervention, with the images then uploaded online.

Elsewhere, cycling was occasionally deployed as an oppositional form of mobility. The closure on security grounds of a towpath and cycle-route generated a local protest group which staged cycle-based demonstrations, while the Counter Olympics

\footnotetext{
${ }^{14}$ See http://www.thetimes.co.uk/tto/public/cyclesafety/article3313260.ece.

${ }^{15}$ See http://www.tfl.gov.uk/assets/downloads/casualties-in-greater-london-2011.pdf.
} 
Network, which brought together over 50 anti-Olympic groups, used bicycles to stage a rival Olympic torch relay in East London.

Thus, cycling at the 2012 Olympics highlighted the ways in which a particular form of mobility is underpinned by cultural political differences and conflicts. In this particular instance, cycling at 2012 spotlighted forms of contestation between, on one side, national and international symbolism and security, and on the other, everyday local practices and expressions of opposition.

\section{Conclusion}

In this discussion, we have sought to explore how the hosting of the London 2012 Olympics was underpinned by the politics of mobility. The Olympics landed upon some of the UK's least powerful communities. The forced movement of local residents and others for London 2012, and the disappointing social and economic returns for local people from acting as event hosts, served to compound these social divisions. The Olympic mobility system in and around Newham inaugurated a threespeed city which, in tandem with a mobility panic, facilitated the relatively free movement of 'Games globals', the corporate kettling of Olympic tourists and visitors, and the restricted mobilities of local people.

In examining the mobility politics at London 2012 , we have sought to break new sociological ground in three main ways: first, by advancing the first sustained mobilities-based analysis of a mega-event; second, by extending the mobilities paradigm through setting out six themes of mobility politics at London 2012 , and through new keywords and concepts, notably the three-speed city, entryability, mobility panics, instrumental mobility, and corporate kettling; and third, by advancing 
sociological understanding of sport and other mega-events with reference to mobility issues.

The six themes of mobility politics at London 2012 should be understood as deeply interconnected rather than mutually isolated, such that each one is tied to the others at everyday level. For example, we may turn to consider the mobility experiences of Olympic visitors and spectators: these populations were transported at steady speed along Olympic rail and underground routes (mobility systems), avoiding slower or more dangerous transport systems (contested politics of mobility), and minimizing contact with relatively poor and disenfranchised local areas (social context); they were then directed, through a process of corporate kettling, into the Westfield shopping mall (event construction, commercial mobilities); privileged ticket-holders subsequently filed through layers of event security and into the Olympic Park, to buy products, watch and cheer the sport, and to gaze at empty seats in prime viewing positions (event construction, commercial mobilities, mobile politics of exclusion).

We would argue that the mobilities perspective offers many benefits for the sociological analysis of mega-events and other fields of contemporary social life. First, the mobilities paradigm captures the increasing centrality of physical, communicative, virtual, digital and other forms of mobility for the everyday construction of social life. Second, the paradigm registers the contemporary importance of mobility as a political theme and issue, for example with regard to the planning and implementation of transport systems, the social inequalities surrounding access to mobility systems and to different speeds of movement, and the role of expert systems in directing or guiding population movements (such as through mobility panics and corporate kettling). Third, global mega-events such as the Olympics serve to crystallize, and to render more visible, these broader forms of 
mobility politics and power relations. Global mega-events have an enormous longterm impact on host cities and are the subject of continuous discussion within the public sphere; and, they must be planned and staged within tight schedules, usually with strong reference to mobility systems and associated legacies of urban regeneration. Hence, these events provide ideal case-study settings for the critical application and development of the mobilities paradigm.

Future research at sport mega-events would benefit from further critical application of the mobilities paradigm - with its attendant theories and concepts - to investigate these themes and issues for host communities and cities. Such research may also examine an issue that has been beyond the scope of this paper: that is, how, in terms of mobilities, socio-spatial processes interconnect with socio-temporal developments. This entails examining the long-term impacts of mega-events for the host communities, after the urban festival has left town.

\section{Acknowledgements}

The research for this paper was financed by a grant from the UK Economic and Social Research Council (ESRC), award number RES 062-23-2738. We wish to thank the journal editor Don Slater and three anonymous reviewers for their very helpful and constructive comments and criticisms on an earlier version of this paper.

\section{References}

Armstrong, G. 1996 Football Hooligans: Knowing the Score, Oxford: Berg.

Bauman, Z. 2000 Liquid Modernity, Cambridge: Polity.

Beck, U. 2000 'The Cosmopolitan Perspective: Sociology of the Second Age of Modernity', British Journal of Sociology, 51(1): 79-105. 
Beck, U., Giddens, A. and Lash, S. 1994 Reflexive Modernization, Stanford: Stanford University Press.

Beckmann, J. 2001 'Heavy Traffic: Paradoxes of a Modernity Mobility Nexus', in L.D. Neilsen and H.H. Oldrup (eds) Mobility and Transport: An Anthology, Copenhagen: Danish Transport Council.

Bhabha, H. 1996 'Unsatisfied: Notes on Vernacular Cosmopolitanism', in L. GarciaMorena and P.C. Pfeifer (eds) Text and Nation, London: Camden House.

Boden, D. and Molotch, H. 1994 'The Compulsion to Proximity', in B. Friedland and D. Boden (eds) Nowhere: Space, Time and Modernity, Berkeley: University of California Press.

Bourdieu, P. 1998 On Television, New York: The New Press.

British Sociological Association 2002 'Statement of Ethical Practice', available at http://www.britsoc.co.uk/media/27107/StatementofEthicalPractice.pdf.

Büscher, M. and Urry, J. 2009 'Mobile Methods and the Empirical', European Journal of Social Theory, 12(1): 99-116.

Büscher, M., Urry, J. and Witchger, K. (eds) 2010 Mobile Methods, London: Routledge.

Byrne, D. 1998 Complexity Theory and the Social Sciences, London: Routledge.

Chatziefstathiou, D. and Henry, I.P. 2012 Discourses of Olympism, Basingstoke: Palgrave. 
Cornelissen, S. 2012 "Our Struggles are bigger than the World Cup": Civic Activism, State-Society Relations and the Socio-Political Legacies of the 2010 FIFA World Cup', British Journal of Sociology, 63(2): 328-348.

Cresswell, T. 2006 On the Move, London: Routledge.

DCMS (Department of Culture, Media and Sport) 2010 Plans for the Legacy from the Olympic and Paralympic Games, December 2010, London: DCMS.

Degen, M. 2004 'Barcelona's Games: The Olympics, Urban Design, and Global Tourism', in M. Sheller and J. Urry (eds) Tourism Mobilities, London: Routledge.

Elliott, A. and Urry, J. 2010 Mobile Lives, Cambridge: Polity.

Giulianotti, R. 1999 Football: A Sociology of the Global Game, Cambridge: Polity.

Giulianotti, R. and Robertson, R. 2004 'The Globalization of Football: A Study in the Glocalization of the "Serious Life"', British Journal of Sociology, 55(4): 545-568.

Harvey, D. 1991 The Condition of Postmodernity, Oxford: Blackwell.

Hobbs, D. 1989 Doing the Business, Oxford: Oxford University Press.

Kaufmann, V. 2010 'Mobile Social Science: Creating a Dialogue among the Sociologies', British Journal of Sociology, 61: 367-372

Knowles, C. 2010 'Mobile Sociology', British Journal of Sociology, 61: 373-379.

Lash, S. and Urry, J. 1994 Economies of Signs and Space, London: Sage.

Lenskyj, H. 2002 The Best Olympics Ever? The Social Impacts of Sydney 2000, Albany, NY: SUNY Press.

Lenskyj, H. 2008 Olympic Industry Resistance, Albany, NY: SUNY Press. 
MacAloon, J.J. 1981 This Great Symbol: Pierre de Coubertin and the Origins of the Modern Olympic Games, Chicago: University of Chicago Press.

Puttnam, R. 2000 Bowling Alone: The Collapse and Revival of American Community, New York: Simon \& Schuster.

Robertson, R. 1992 Globalization, London: Sage.

Roche, M. 2000 Megaevents and Modernity: Olympics, Expos and the Growth of Global Culture, London: Taylor and Francis.

Rowe, D. 2012 'The Bid, the Lead-Up, the Event and the Legacy: Global Cultural Politics and Hosting the Olympics', British Journal of Sociology, 63(2): 285-305.

Sheller, M. and Urry, J. 2006 'The New Mobilities Paradigm', Environment and Planning A, 38: 207-226.

Thrift, N. 1996 Spatial Formations, London: Sage.

Urry, J. 2000a Sociology Beyond Societies, London: Routledge.

Urry, J. 2000b ‘Mobile Sociology', British Journal of Sociology, 51: 185-203

Urry, J. 2002 'Mobility and Proximity', Sociology, 36: 255-274.

Urry, J. 2003 'Social Networks, Travel and Talk', British Journal of Sociology, 54: 155-175.

Urry, J. 2007 Mobilities, Cambridge: Polity.

Urry, J. 2008 'The London Olympics and Global Competition: On the Move', 21st Century Society, 3: 289-93. 
Vertovec, S. 2004 'Cheap Calls: The Social Glue of Migrant Transnationalism', Global Networks 4(2): 219-24.

Virilio, P. 1986 Speed and Politics, New York: Semiotext(e).

Wellman, B. 2001 'Physical Place and Cyber Place: The Rise of Networked Individualism', International Journal of Urban and Regional Research, 25: 227-252. 